\title{
Diffusion of Corporate Philanthropy in Social and Political Network Environments: Evidence from China
}

\author{
Wenqing $\mathrm{Wu}^{1}{ }^{1}$, Kexin $\mathrm{Yu}^{1}$, Chien-Chi Chu ${ }^{2,3, * \mathbb{D}}$, Jie Zhou ${ }^{4, *}$, Hong $\mathrm{Xu}^{4}$ \\ and Sang-Bing Tsai ${ }^{5,6,7, *(1)}$ \\ 1 College of Management and Economics, Tianjin University, Tianjin 300072, China; \\ wenqingw@tju.edu.cn (W.W.); kionayu@163.com (K.Y.) \\ 2 Department of Finance, Business School, Shantou University, Shantou 515063, China \\ 3 Research Institute for Guangdong-Taiwan Business Cooperation, Shantou University, Shantou 515063, China \\ 4 College of Tourism and Service Management, Nankai University, Tianjin 300071, China; xuhonhg@126.com \\ 5 Zhongshan Institute, University of Electronic Science and Technology of China, Guangzhou 528400, China \\ 6 China Academy of Corporate Governance, Nankai University, Tianjing 300071, China \\ 7 College of Business Administration, Capital University of Economics and Business, Beijing 100070, China \\ * Correspondence: jqzhu@stu.edu.cn (C.-C.C.); zhoujie_1980@126.com (J.Z.); sangbing@hotmail.com (S.-B.T.)
}

Received: 5 April 2018; Accepted: 28 May 2018; Published: 6 June 2018

check for updates

\begin{abstract}
Based on the strong influence social networks have on managerial decision-making, as an important aspect of the strategic decision of the company, it is necessary to study how corporate social responsibility (CSR) actions could be affected by social networks. An analysis of 1725 Chinese listed firms and 40,484 executives from 2010 to 2014 showed that corporate philanthropy behavior will diffuse in social networks; more concretely, the higher the degree of social network centrality, the higher the enterprise's donation level. Furthermore, the results also show that the role of social network centrality on corporate donation levels can be moderated by political connections. This study offers empirical evidence for developing a theoretical framework of CSR interaction and communication relevant to social networks, and offers insights into corporate philanthropy behavior based on social networks.
\end{abstract}

Keywords: corporate philanthropy; information transfer; political connections; social capital; social network; social network centrality

\section{Introduction}

Over the past several decades, an increasing amount of literature has focused on the influence of networks on corporate operations. Social networks have been used to explain a wide range of outcomes, including performance [1-4], firm policies [5-7], executive compensation [8], knowledge sharing $[9,10]$, innovation [11], and ethical behavior [8,12]. Many scholars have studied the role of corporate philanthropy, an important aspect of a company's strategic decisions, on the enterprise itself and on society. From the perspective of the political relations, some scholars believe that corporate donations enhance a company's political connection with the government, thereby enhancing that company's competitiveness. For example, Hadani and Coombes [13] suggested that corporate donations may allow some firms to stand out from others when faced with political uncertainty. Porter and Kramer [14] found that a company's competitiveness can be improved by using corporate philanthropy as a tool. In addition, firms that are not politically well-connected were shown to benefit more from corporate donations, as gaining political resources is more critical for such firms [15]. On the other hand, some scholars doubt the positive relationship between nonmarket strategy such as 
corporate political activity and corporate performance. According to Mellahi, et al. [16], over one-third of the studies in their sample do not find positive performance effects of nonmarket strategies. In short, within the political and social network environment, corporate philanthropy is an important issue that needs further study. However, few of them observe the influence on corporate philanthropy from a network perspective, especially in developing countries.

Charitable donations are a strategic and salient component of corporate social performance [14], as well as an important aspect of corporate decision-making. We can analyze the relationship between social networks and corporate donations from two perspectives: information transfer and social capital theory [17]. On the one hand, the ways in which charitable donation behavior is affected by external information has commonly received attention from social psychology [18], economics [19], and other research fields. On the other hand, according to social capital theory [20], studies on the markets of developed countries reveal that social pressure and networks can increase a company's commercial philanthropy [21], or compel them to display "a greater sense of social responsibility" [22]. Therefore, it can be seen that the position of corporate executives in a social network will affect a company's donation level. In particular, the literature has confirmed that donations are affected by social networks from a personal perspective [23-25]. Thus, it is necessary to examine the important, yet understudied aspect of corporate social responsibility (CSR), that is, the relationship between executive social relations and corporate donation behavior.

The social network theory posits that individuals tend to change their preferences and decisions because of other people's actions [26]. In that way, the presence of social networks among senior executives can affect firms' corporate donation decisions [7]. As there is no literature on Chinese market data to study the relationship between the two, we investigate how social network links between pairs of firms influence their corporate donation decisions. In particular, we want to be the first to test whether executives who are socially connected make more similar decisions, which we call the "diffusion effect." To address the first component of the research issue, this study builds upon previous research on corporate philanthropy from an information transmission perspective. We use a matrix to represent the relationships between the listed firms, and then establish a two-stage firm pair model.

After confirming the diffusion effect of social networks [14,17], we investigate the overall effects of social network connections on corporate donations. In addition, we note that the firms' donation behavior is subject to pressure not only from social networks, but also from political networks, especially in developing countries [27]. Firms often build political connections to gain government support and favorable treatment that may effectively mitigate political uncertainties [15]. There are already studies proving that political connections can independently influence the level of corporate donations $[27,28]$. In this paper, we have chosen the executives' employment network to represent the social relationships between firms. Social networks can provide information and resources for executives, and ultimately affect executives' decision-making. From this perspective, we can see that both political connections and social networks can provide access to resources. Political connections also have social attributes: as Scott [29] mentioned in 2000, political associations and connections are also a kind of social network. Thus, political connections should be taken into consideration in our study, especially in China, where firms set a high value on them. Therefore, we believe that political connections have a moderate role in the impact of network connections on donation behavior.

To address the second component of the research question, an ordinary firm-level model is established to examine whether the position of firms in the social network influences donation behaviors. According to the analysis, we also added the interaction items of social network centrality and political connections to the framework to more thoroughly explore the impact mechanism of social networks.

In a nutshell, the goal of this paper is to analyze how social networks affect donation behavior. The core premise of this theoretical framework is that the research issue is a combination of two related problems: whether corporate charitable behavior diffuses through a social network; and if so, the means by which this is done. The results of an analysis of data on a sample of 1725 Chinese 
listed companies and 40,484 executives gathered between 2010 and 2014 suggest that the donation behavior of enterprises has a diffusion effect on social networks. Based on this, our results indicate that the position of a company in the social network is positively related to its donation level. We have also discovered that some political connections can reduce the effects of social network centrality on corporate donations.

The rest of the paper is organized as follows. The second section provides a review and discussion of the relevant literature, developing our theoretical arguments and hypotheses. The third section presents the methodology, including the sample data, variables, and models. The fourth section reveals the results of the analyses. Finally, the paper concludes with a discussion of the study's contributions, limitations, and implications.

\section{Literature Review and Hypotheses}

\subsection{The Diffusion Effect of Social Networks on Corporate Donations}

In the past, several studies have highlighted the role of social networks in the transfer of privileged information. For example, Cohen, Frazzini and Malloy [1] used social networks to identify information transfers in the stock market, and the results showed that social networks may be an important mechanism for how information flow affects asset prices. Cao, Dhaliwal, Li and Yang [3] found that independent directors with more social connections earn higher returns in their stock transitions than do others. Indeed, having additional internal and external information is beneficial to corporations in order to obtain key resources [30], reduce market transaction costs [31], and create competitive advantages [32]. Based on this, it can be concluded that external information has an impact on enterprise decision-making. It is also meaningful to understand how executives learn and imitate such information, because we are living through an unprecedented explosion of information today, and executives are vulnerable to being overwhelmed by too much complex information [26]. From the perspective of corporate donations, firms close to one another whose executives are affected by information from "neighboring firms" make similar decisions [33,34].

Recent studies also reveal that social information affects personal donations [24]; however, few studies have been conducted on this topic in the corporate world. It is important to explore the relationship between the two on the corporate level, as donation behavior is a typical decision-making behavior found within corporations. It is natural for corporations to receive donation behavior information from a "neighboring firm" through their social network, and this information, in turn, controls the company's donation levels by affecting its executives' behavior.

At the same time, scholars have highlighted that CSR's influence on companies' management and strategy is growing [35,36]. Thus, it is important to continue to explore the motivation of corporate donations. While there is extensive literature related to driving factors, such as firm value [37], moral motivations [38], and political motivations [27], an examination of the ways in which social interactions affect people's charitable behavior has not been fully developed [39]. Such studies mainly focus on psychological and cultural backgrounds, emphasizing the interaction and connection between people. Gautier and Pache [40] reviewed about 30 years' worth of academic research on corporate philanthropy, and found that there were only five articles that investigated the impact of executives' social networks on firm donations. So far, the existing literature has proved that social networks have a direct impact on CSR [17,41], but most of these studies are rather limited at the firm level, as well as in terms of case studies.

Based on these arguments, we address this gap by considering the diffusion effect of the social network on donation behavior within firm pairs. To compare differences between two companies' donation levels caused by a social network, we implemented the two-stage model used by Fracassi [26] in the first part of our research. If the expected impact exists, the firm pairs with social connections are bound to have similar donation amounts. On these grounds, our first hypothesis is as follows: 
Hypothesis 1. The donation behavior of corporations has a diffusion effect in their social networks; two corporations with social connections are more similar in terms of their donation levels.

\subsection{The Effect of Social Networks Centrality on Corporate Donations}

As we know, social networks have always been fiercely debated upon in the literature. Additionally, concepts of social capital have frequently been considered in the literature [42-44]. Such studies mainly focus on the relationships between different kinds of social networks and the social capital embedded in them. Several scholars have also combined donation studies with related issues [45].

Social capital refers to the resources embedded in personal social networks, such as power, wealth, prestige, etc.; these resources exist in the relationships between people, and one must be connected with others to obtain them [20]. Witt [46] pointed out that network conditions can help enterprises integrate into the market and the local network, and adapt to local political, cultural, and economic conditions. Huggins [47] proposed that firms can gain access to knowledge through network capital to enhance expected economic returns. As a result, social contact can become an integral part of a business that cannot be separated from a firm's overall strategy. Therefore, as an entrepreneur's management decision, the influence of social relations should be taken into consideration when analyzing the level of corporate donation. As firms usually aspire to achieve a positive reputation and prominent status in their networks $[17,48]$, they often aim to meet the expectations of the other members in the network by donating more.

In order to measure the degree of social connections of the corporations, we introduced a social network centrality variable. Social network centrality is a collection of measures that describe an individual's position in a social network [4], representing their ability to influence economic decision-making. Several common measures of centrality have been constructed in previous literature [49]. In this paper, we use the number of direct ties a corporation has with other firms in the network to measure the network centrality. In general, high centrality means higher status and power. This definition is similar to that provided by Lu, Shailer and Wilson [17], whose study also examined some kinds of donations. They used the number of directors' relationships with other corporations, finding that these networks influence corporate political donations. The above analysis indicates that enterprises in important positions need to meet the expectations of other members to a higher degree. Thus, our second hypothesis is as follows:

Hypothesis 2. The higher the degree of a social network's centrality, the higher the enterprise's donation level.

\subsection{The Moderating Effect of Political Connections}

Political connections are crosslinks between business and government; they are an important asset or political strategy [28] for the economy as a whole, as well as for individual businesses within a given country or emerging economy $[50,51]$. Some scholars believe that political connections provide access to information and other licenses for corporations [52], which can reduce the increasing donation behavior of executives aiming to obtain added resources and prestige. However, some scholars have come to the opposite conclusion [53], which can reduce the increasing donation behavior of executives aiming to obtain added resources and prestige. However, some scholars have come to the opposite conclusion [53]: they believe that these political connections will lead to an increase in corporate donations. The existence of these contradictory ideas leads us to consider the classification of political connections. Zhang, Marquis and Qiao [27] distinguished two types of managerial political connections-achieved political connections and ascribed bureaucratic connections-and found that the two react differently to government pressure to donate. Marquis and Qian [53] summed up that there are generally two types of political connections. Thus, we divided them into two categories according to the type of connection: Connections with People's Congress/Chinese People's Political Consultative Conference (NPC/CPPCC) members and connections with government officials [53]. 
The literature suggests that the former may have greater symbolic meaning and the latter greater substantive meaning.

First, for the NPC/CPPCC member connections, executives are generally chosen by the government as corporate elites. In other words, these types of political connections are generally obtained after company executives have attained certain achievements and reached a particular social status during their tenure. Therefore, executives with this background may pay more attention to their social reputation and public image, and tend to increase their donation level to achieve a positive public image [27]. This connection's influence on corporate donation is in accordance with social network connections. When companies obtain the resources they require through political connections, their motivation for obtaining resources through social connections will be reduced. In addition, it is thought that when the corporate donation level is increased due to influence from one of the two sides, the influence of the other side will be greatly reduced. Thus, we propose the following hypothesis:

Hypothesis 3A. The higher the degree of the NPC/CPPCC member connections, the weaker the impact of social network centrality on the level of corporate donations.

Second, contrary to the NPC/CPPCC member connections, executives with connections of government officials usually have access to the government prior to becoming involved with the enterprise, and thus, there is no need to maintain ties with the government [27]; even if executives have left the government, the listed companies can still be supported by the government, and the company does not have to rely on a commitment to social responsibility in order to receive "favors" from the government. Theoretically, previous government work experience has made such individuals very aware of government officials and activities [54], and stable ties secured by connections with government officials will reduce their eagerness to improve a corporation's value through donations. Compared to the former type of political connections, relationships with government officials reveal that the enterprise attaches great importance to the establishment of a political background from the very beginning, and will ensure the introduction of managers with political experience. Therefore, when they are influenced by donation information from other companies, they will be more active in social responsibility. Thus, we propose the following hypothesis:

Hypothesis 3B. The higher the degree of connections with government officials, the stronger the impact of social network centrality on the level of corporate donations.

\section{Research Method}

\subsection{Sample and Data Collection}

All companies listed in China's A share market before 2010 were included, with a sample interval of 2010 to 2014. The listed companies' Directors Council members and senior management personnel were used as the basis to build the company employment network; senior management personnel include the chairman, CEO, general manager, deputy general manager, financial manager, board secretary, and other personnel stipulated in the company's articles of association. Our initial sample contained 2044 listed companies. The samples were screened, and the following were removed: (1) financial companies and (2) special treatment companies. The reporting structure of China's financial sector is different from others, and so it is generally not compared with other sectors. ST companies usually refer to listed companies with abnormal financial or other situations. They are more likely to have false information disclosure problems, and are not suitable for comparison with other listed companies. After screening, the samples included 1725 listed companies and 40,484 senior managers and directors (hereinafter referred to as executives). The data is mainly from the CSMAR database (China Stock Market and Accounting Research Database), which is widely used in the study of listed companies in China. In addition, data not found in the CSMAR database were obtained by 
analyzing the annual reports of the listed companies, retrieving Sina Financial websites, and searching web pages.

Information on political connections came from the executives' resume projects on CSMAR; the biographical items are text information; therefore, we were able to manually sort out the executives' political connections. According to the actual conditions, we set up two variables to measure the political connections: political connections with government officials and political connections with NPC/CPPCC members.

\subsection{Dependent Variable}

We obtained the company donation data from the financial statements database within the CSMAR database. The database includes two items: donation expenditure and public welfare donations. If the public welfare donation is a detailed account of the donation expenditure, the donation expenditure data were regarded as the amount of the donation. If the two subjects were parallel, both were regarded as the amount of the donation. Furthermore, the donation data were recorded as zero when the donation expenditure data were zero, and it was regarded as missing data if the donation expenditure data were missing; the corresponding companies were deleted in the subsequent study. The logarithm of the donation amount as the index was used to measure the level of corporate donation (DON_LEi,t). Since the independent variables in our study lag for one year, the sample interval of donation level data is from 2011 to 2015.

\subsection{Independent Variables}

The CSMAR database provides annual resume data for executives. For Hypothesis 1, we used annual employment information to establish a dummy variable at the firm pair level to measure the social connections between the two firms. In order to ensure the quality of the data, we distinguished between executives with the same names by giving each executive set a specific name. We first established a 40,484-by-40,484 undirected (symmetric) binary adjacency matrix according to the society connections between all the firm pairs. If two firms appointed one executive at the same time, or two executives from two firms worked for a third firm at the same time, it is believed that the two firms are socially related.

As this section studies the relationship between social connections and donation levels at the firm pair level, a social network dummy variable (NET) was established between firms based on the executive network. If there is a social connection between employees of the two companies, the value of the dummy variable is one; otherwise, it is zero.

In order to test Hypotheses 2 and 3, we established an index to measure the degree of social network centrality between the firms. After generating an undirected employment network matrix diagram for all the firm samples, the centrality of each node (firm) was used as an index to measure the degree of social relevancy. For the undirected matrix with n nodes, the degree of node 1 was the ratio of the sum of the direct connections between node $i$ and other $N-1$ nodes, divided by the total number of nodes in the network, expressed in Model (1). Firms with strong centrality often connect with many other firms, and have more opportunities to obtain resources and learn behavior from other firms through the network.

$$
\text { Degree }_{i}=\frac{\sum_{j=1}^{N} N E T_{i j}(i \neq j)}{N-1}
$$

\subsection{Moderator Variable}

To the above analysis, researchers added the interaction items of DEGREE and political connections to examine Hypotheses 3A and 3B. Political connections are a common phenomenon in enterprises at home and abroad. Broadly speaking, they can be regarded as a kind of social connection. Political connections were divided into two categories: connections with NPC/CPPCC members 
and connections with government officials. According to the resume information of executives, we manually sorted the government job information for executives.

The NPC/CPPCC member connections refer to the connections executives build with the government by being members of political councils, such as the National People's Congress (NPC), the only legislative body in China, or the Chinese People's Political Consultative Conference (CPPCC), an advisory board for the Chinese government. When constructing variables, in order to ensure that only the political elites were considered, we selected only national or provincial-level political connections. This variable is represented by REPRESENT_PC, and was calculated by the number of executives divided by the number of firm executives.

Connections with government officials refer to the connections between individuals who have been or are being employed by government departments and the government. In China, the national administration can be roughly divided into five levels: state, department, bureau, division, and section. If an executive has served or is serving at the division level or above, we believe there is a connection with a government official. The proportion of executives who have political connections in the listed companies is used to measure political connections with government officials, and the variable is represented by BUREAU_PC.

\section{Empirical Results}

\subsection{The Empirical Model of Network Diffusion Effect on Firm Pair Level}

We set up a two-stage firm pair model to examine whether two socially connected firms had more similar donation levels than those that did not have social connections. In the first stage of the model, the firm's donation level $\left(D O N_{-} L E_{i, t}\right)$ is used as the dependent variable, and the variables that influence the level of corporate donation are used as control variables $\left(\mathrm{CON}_{i, t-1}\right)$ for regression, as shown in Model (2). The residual of Model (2) is the part of the donation level that cannot be explained by the selected control variables: that is, as a measure of the impact of the social network on the donation level. Next, we define the absolute difference of residuals obtained by the two firms in Model (3) (DON_DS $\left.S_{i, j, t}\right)$ as the donation level difference of the two.

$$
\begin{gathered}
D o n \_L E_{i, t}=\alpha_{0}+\alpha_{1} C O N_{i, t-1}+\epsilon_{i, t} \\
\text { Don_DS } S_{i, j, t}=\operatorname{abs}\left(\epsilon_{i, t}-\epsilon_{i, t}\right)
\end{gathered}
$$

Through the literature review, we determined that we must add the following control variables in Model (2); all of these variables can theoretically affect the level of corporate donation, and their impact has been proven by empirical evidence. We measured the company size (FIRM_SIZE) by the logarithm of the total assets of the company at the end of the year. The slack cash (SLACK_CASH) is expressed by the total cash flow of the company divided by the total assets [15]. Advertising intensity (ADVE_INTE) is expressed in terms of the logarithm of annual sales expenses. We use the date of the sample year minus the company's IPO date to represent the company's IPO age as (AGE_IPO), which can control the impact of the stock market on the company [27]. We controlled for the size of executive boards by the number of executives in the company, denoted as NO_EXEC. Whether the chairman and the general manager (CEO) positions are held by the same person determines the concentration of management power [55]. If the company chairman and general manager (CEO) is the same person, the dummy variable DUALITY value is one; conversely, if the positions are held by different people, the value is zero. We use the return on assets (ROA) to measure company performance FIRM_PERF, and measure solvency LEVERAGE with the asset liability ratio.

Finally, we add the region-year and industry-year dummy to control the effects of industry and region on regression results. For industry, we use the China Securities Regulatory Commission Industry Classification Standards to classify the samples. For region, we divide the firms into three categories according to registered places. The Chinese regional economy is formed according to the long-term 
evolution of the different levels of economic development and geographical location. Mainland China can be divided into three major economic regions: eastern, central, and western.

In the second-stage model, the $D O N \_D S_{i, j, t}$ calculated is the dependent variable, which measures the similarity between the donation levels of the companies. The employment network variable NET is the independent variable of the second-stage model, and it is used to measure whether there is a social connection between two companies. The second-stage model is shown as Model (4):

$$
D o n \_D S_{i, j, t}=\beta_{0}+\beta_{1} N E T_{i, j, t-1}+\beta_{2} C_{i, j, t-1}+\eta_{i, t}
$$

The control variables $\left(C_{i, j, t-1}\right)$ are also added to linear regression Model (4), where ABS_ASEET represents the difference in total assets between the two firms; the variable is used to control the impact of the firm size on the regression results. ABS_AGE_EXEC represents the difference between the average ages of the executives in the two firms. ABS_NO_EXEC and ABS_WOMEN represent the difference in the number of executives and the proportion of female executives, respectively. We also added NO_EXEC and AGE_EXEC, which are the sum of the executives and the average age of the executives in the two firms, respectively.

In addition to the full sample regression, we also conducted regression analysis on samples from the same industries/regions as well as different industries/regions.

\subsection{The Empirical Model of Network Effect on Firm Level}

In the last section, we analyze whether the existence of social networks can affect corporate donation behavior. However, we cannot judge whether the impact of the network on corporate donation levels is positive or negative through the results. Therefore, this section will analyze the impact of social network centrality on corporate donation. Simultaneously, we will add political connection variables into the model to study their impact on corporate donations, and further explore the effect of the interaction terms between them and the social network centrality.

In this section, we establish linear regression Model (5) to test Hypothesis 2. Consistent with the first-stage model in the previous section, corporate donation level (the logarithm of donation amount) is used as a dependent variable, and explanatory variables and control variables are added to the regression to examine the impact of social network centrality on corporate donation behavior, as shown in Model (5):

$$
\text { Don_LE } E_{i t}=\beta_{0}+\beta_{1} D E G R E E_{i, t-1}+\beta_{2} C_{i, t-1}+\eta_{i, t}
$$

In Models (6) and (7), we continue to add moderator variables based on Model (5) to test the impact of political connections on the relationship between ownership concentration and corporate donation.

$$
\begin{gathered}
\text { Don_LE } E_{i t}=\beta_{0}+\beta_{1} D E G R E E_{i, t-1}+\beta_{2} R E P R E S E N T \_P C_{i, t-1}+\beta_{3} C_{i, t-1}+\eta_{i, t} \\
\text { Don_LE } E_{i t}=\beta_{0}+\beta_{1} D E G R E E_{i, t-1}+\beta_{2} \text { BUREAU_PC } C_{i, t-1}+\beta_{3} C_{i, t-1}+\eta_{i, t}
\end{gathered}
$$

Models (8) and (9) are based on Models (6) and (7), with the addition of the interaction items of the moderator variables and the dependent variable, to test whether they affect the relationship between social network centrality and the donation level, and draw more conclusions about how social network centrality affect the corporate donation level.

$$
\begin{gathered}
\text { Don_LE } E_{i t}=\beta_{0}+\beta_{1} D E G R E E_{i, t-1}+\beta_{2} \text { BUREAU_PC } C_{i, t-1} \\
+\beta_{5} D E G R E E_{i, t-1}{ }^{*} B U R E A U_{i, t-1}+\beta_{7} C_{i, t-1}+\eta_{i, t} \\
\text { Don_LE } E_{i t}=\beta_{0}+\beta_{1} D E G R E E_{i, t-1}+\beta_{2} R E P R E S E N T \_P C_{i, t-1} \\
+\beta_{6} D E G R E E_{i, t-1}{ }^{*} \text { REPRESENT_PC } C_{i, t-1}+\beta_{7} C_{i, t-1}+\eta_{i, t}
\end{gathered}
$$


Similar to the last section, the main control variables that affect the level of corporate donation are determined, which include the firm size, slack cash, advertising intensity, IPO age, duality, corporate performance, solvency, and the number of executives. We also added dummy variables to reduce the impact of year, region, and industry on regression results. In addition, according to the estimated results of the second-stage model in the last section, the proportion of female executives also affects the donation level; therefore, we added the proportion of female executives in the control variables (WOMEN).

The summary statistics of the variables are shown in Tables 1 and 2:

Table 1. Summary statistics of firm level variables.

\begin{tabular}{cccc}
\hline Variables & Mean & Std. Dev & No. of. Obs \\
\hline DON_LE & 10.770 & 4.838 & 6581 \\
FIRM_SIZE & 22.106 & 1.302 & 6581 \\
SLACK_CASH & 0.040 & 0.083 & 6581 \\
ADVE_INTE & 17.868 & 3.038 & 6581 \\
AGE_IPO & 10.220 & 6.073 & 6581 \\
FIRM_PERF & 0.042 & 0.074 & 6581 \\
NO_EXCE & 7.762 & 1.287 & 6581 \\
DUALITY & 0.137 & 0.3435 & 6581 \\
LEVERAGE & 0.489 & 1.548 & 6581 \\
\hline
\end{tabular}

Table 2. Summary statistics of firm pair level variables.

\begin{tabular}{cccc}
\hline Variables & Mean & Std. Dev & No. of. Obs \\
\hline NET & 0.012 & 0.109 & $4,697,720$ \\
NET (within industry) & 0.012 & 0.108 & $1,675,248$ \\
NET (cross industry) & 0.012 & 0.110 & $3,022,472$ \\
NET (within region) & 0.014 & 0.118 & $2,355,591$ \\
NET (across region) & 0.010 & 0.099 & $2,342,129$ \\
Same industry & 0.357 & 0.479 & $4,697,720$ \\
Same region & 0.501 & 0.500 & $4,697,720$ \\
NO_EXEC & 40.721 & 7.164 & $4,697,720$ \\
AGE_EXEC & 48.663 & 2.254 & $4,697,720$ \\
ABS_ASSET & $2.11 \times 10^{10}$ & $1.03 \times 10^{11}$ & $4,697,720$ \\
ABS_NO_EXEC & 5.322 & 4.510 & $4,697,720$ \\
ABS_WOMEN & 0.114 & 0.0882 & $4,697,720$ \\
ABS_AGE_EXEC & 3.451 & 2.631 & $4,697,720$ \\
\hline
\end{tabular}

\subsection{The Empirical Results of Network Diffusion Effect}

The regression results of the first-stage model are shown in Table 3. The coefficients and significance results are basically consistent with previous scholars' conclusions. Table 4 lists the regression results of the second-stage models, where the dependent variable is the difference in the level of donation between companies $\left(D O N \_D S_{i, j, t}\right)$. Our main focus in this regression is the coefficient of NET. As reflected in Hypothesis 1, we believe that corporate donations can be spread through a social network existing between executives. When such a social network between two companies is small, the disparity in donation levels is much smaller. Therefore, the employment network variables (NET) that represent social networks should have a significant negative coefficient. If the results indicate otherwise, this means that our hypothesis is invalid. It is worth mentioning that this study cannot draw the direction of network impact on the donation level; the purpose of the analysis is to prove the impact of the network on corporate donations. 
Table 3. Network diffusion effect results: first-stage regression.

\begin{tabular}{cc}
\hline & DON_LE \\
\hline FIRM_SIZE & $0.976^{* * *}$ \\
& $(10.84)$ \\
SLACK_CASH & $2.453^{* * *}$ \\
& $(2.95)$ \\
ADVE_INTE & $0.142^{* * *}$ \\
& $(4.44)$ \\
AGE_IPO & $-0.064^{* * *}$ \\
& $(-4.66)$ \\
FIRM_PERF & $5.433^{* * *}$ \\
& $(3.71)$ \\
NO_EXCE & $0.248^{* * *}$ \\
DUALITY & $(2.76)$ \\
LEVERAGE & $0.208(1.05)$ \\
Industry-year fe & $0.076^{* * *}$ \\
Region-year fe & $(2.71)$ \\
R2-sq & yes \\
No. of obs. & yes \\
\hline
\end{tabular}

The dependent variable is the companies' donation level. ${ }^{* * *}$ indicate significance at the 10,5 , and 1 percent levels, respectively. The OLS (We analyze our questions by ordinary least squares regression, hereinafter referred to as OLS.) coefficients are reported, with the $t$-statistics in parentheses. Standard errors are corrected for by clustering the error term at the firm level (Petersen 2009). The constant is omitted.

In Model (1) in Table 4, only the explanatory variable NET was added. In theory, the second-stage regression no longer needs control variables, because the first-stage regression already controls for industry, region, year, size, and other necessary factors. The coefficient is significant at the 1 percent level, and its value is -0.2005498 , indicating that two enterprises with social connections are more similar on the donation level. Corporate donation information can be spread through the social network between executives, thereby confirming Hypothesis 1. In Model (2), some control variables were added based on Model (1). First of all, the size and average age of the executives for each firm pair (NO_EXEC and AGE_EXEC) was controlled. These two variables were negatively correlated with the dependent variable. Additionally, the relationship between the NO_EXEC and the dependent variable is not significant, while the AGE_EXEC coefficient is negative and significant, which proves that the aging management team is more stable in terms of donation behavior [26]. Furthermore, the results revealed that the proportion of female executives will affect the similarity of the two donation levels; ABS_WOMEN is the female ratio dissimilarity of the number of executives between firm pairs. The size control variables (asset and executive number) are not significant; however, this does not prove that the impact of size on the level of donation is not significant, as the first-stage model has controlled the firm size. A dummy year was also added to the models.

Furthermore, from the descriptive statistics of Table 2, social connections are more common in the same region. In the first stage of the model, we have controlled the industries and regions, but in order to control the possible heteroscedasticity, two dummy variables (Same industry and Same region) were added in the second stage of the model. Hence, we assume that when the two companies are in the same industry or region, the dummy variable value is 1 ; otherwise, the dummy variable value is 0 . In Table 2, regarding Model (2) we simultaneously added Same industry and Same region dummy variables. Table 4 Model (2) shows that the Same industry and Same region coefficients were negative and correlated significantly with the dependent variables in the full sample. Models (3)-(6) regress the same industry/region models and cross industry/region models, except for Model (3). The conclusions, however, still significantly support Hypothesis 1. 
In the second-stage regression, the R2-sq is low, but this is not necessarily caused by the insufficient explanatory power of independent variables. On the one hand, our sample size is very large, which may affect the goodness of fit of the model; on the other hand, this once again reminds us that there are many factors that influence the relationship between social relationships and behavior. It is a field that warrants further study.

Table 4. Network diffusion effect results: second-stage regression.

\begin{tabular}{|c|c|c|c|c|c|c|}
\hline & (1) & (2) & (3) Same Industry & (4) Cross Industry & (5) Same Region & (6) Cross Region \\
\hline NET & $\begin{array}{c}-0.201 \text { *** } \\
(-3.65)\end{array}$ & $\begin{array}{c}-0.142^{* * *} \\
(-2.70)\end{array}$ & $\begin{array}{l}-0.042 \\
(-2.75)\end{array}$ & $\begin{array}{c}-0.196^{* * *} \\
(-3.50)\end{array}$ & $\begin{array}{c}-0.134^{* *} \\
(-2.36)\end{array}$ & $\begin{array}{c}-0.161^{* *} \\
(-2.35)\end{array}$ \\
\hline Same industry & & $\begin{array}{c}-0.250 * * * \\
(-3.48)\end{array}$ & & & $\begin{array}{c}-0.317^{* * *} \\
(-3.85)\end{array}$ & $\begin{array}{c}-0.177^{* *} \\
(-2.22)\end{array}$ \\
\hline Same region & & $\begin{array}{c}-0.182^{* * *} \\
(-3.04)\end{array}$ & $\begin{array}{c}-0.285^{* *} \\
(-3.42)\end{array}$ & $\begin{array}{c}-0.122 \text { ** } \\
(-1.99)\end{array}$ & & \\
\hline NO_EXEC & & $\begin{array}{l}-0.007 \\
(-1.07)\end{array}$ & $\begin{array}{l}-0.003 \\
(-0.38)\end{array}$ & $\begin{array}{l}-0.008 \\
(-1.29)\end{array}$ & $\begin{array}{c}0.006 \\
(-0.83)\end{array}$ & $\begin{array}{c}-0.017^{* * *} \\
(-2.68)\end{array}$ \\
\hline AGE_EXEC & & $\begin{array}{c}-0.062 * * * \\
(-3.07)\end{array}$ & $\begin{array}{l}-0.037 \\
(-1.37)\end{array}$ & $\begin{array}{c}-0.075^{* * *} \\
(-3.55)\end{array}$ & $\begin{array}{c}-0.077^{* * *} \\
(-3.42)\end{array}$ & $\begin{array}{c}-0.048^{* *} \\
(-2.19)\end{array}$ \\
\hline ABS_ASSET & & $\begin{array}{c}-5.39 \times 10^{-14} \\
(-0.15)\end{array}$ & $\begin{array}{c}-2.92 \times 10^{-14} \\
(-0.03)\end{array}$ & $\begin{array}{c}-1.89 \times 10^{-14} \\
(-0.05)\end{array}$ & $\begin{array}{c}-1.18 \times 10^{-13} \\
(-0.31)\end{array}$ & $\begin{array}{c}-3.26 \times 10^{-14} \\
(-0.10)\end{array}$ \\
\hline ABS_NO_EXEC & & $\begin{array}{c}-0.6 .93 \times 10^{-4} \\
(-0.10)\end{array}$ & $\begin{array}{l}-0.011 \\
(-1.12) \\
\end{array}$ & $\begin{array}{l}0.004 \\
(0.57)\end{array}$ & $\begin{array}{l}0.005 \\
(0.61)\end{array}$ & $\begin{array}{c}-0.006 \\
(0.87) \\
\end{array}$ \\
\hline ABS_WOMEN & & $\begin{array}{l}0.519 * \\
(1.74)\end{array}$ & $\begin{array}{l}0.547 \\
(1.32)\end{array}$ & $\begin{array}{l}0.515 \\
(1.62)\end{array}$ & $\begin{array}{l}0.493 \\
(1.41)\end{array}$ & $\begin{array}{l}0.553 \\
(1.63)\end{array}$ \\
\hline ABS_AGE_EXEC & & $\begin{array}{l}0.010 \\
(0.91)\end{array}$ & $\begin{array}{l}0.018 \\
(1.19)\end{array}$ & $\begin{array}{l}0.006 \\
(0.49)\end{array}$ & $\begin{array}{l}0.010 \\
(0.79)\end{array}$ & $\begin{array}{l}0.011 \\
(0.95)\end{array}$ \\
\hline Year FE & no & Yes & Yes & Yes & Yes & Yes \\
\hline R2-sq & 0.000024 & 0.003 & 0.003 & 0.002 & 0.003 & 0.003 \\
\hline No. of obs & 4697720 & 4697720 & 1675248 & 3022472 & 2355591 & 2342129 \\
\hline
\end{tabular}

The dependent variable is the difference of the donation level between the companies. ${ }^{*}, * *$ and ${ }^{* * *}$ indicate significance at the 10,5 , and 1 percent levels, respectively. The OLS coefficients are reported, with the $t$-statistics in parentheses. Standard errors are corrected for by clustering the error term at the firm level. The constant is omitted.

\subsection{The Empirical Results of the Network Centrality Effect}

The results of Table 5 verify Hypotheses 2 and 3A. For Hypothesis 2, the coefficient of network centrality DEGREE is significantly positive (for models (1) to (5): $\beta>0, p<5 \%$ ). This indicates that the higher the centrality of social network, the higher the donation level of the enterprise. Overall, we find strong evidence that companies that are more centrally positioned in a network have higher donation levels, suggesting that social connections not only affect the similarity of firms' donation behavior, bu also influence their total donations. Model (2) confirms that there is a significant positive correlation between the NPC/CPPCC connections and the corporate donation levels. Model (4) contains the interaction item of NPC/CPPCC member connections and social network centrality, and the coefficient of the item is negative $(\beta=-0.7385246, p<1 \%)$. It is concluded that the political connections of NPC/CPPCC members will buffer the network motivation of corporate donations. Thus, in China, a listed company with higher network centrality will provide more donations, but if the company has high NPC/CPPCC member connections at the same time, the positive impact of the political background on donations will be reduced.

For Hypothesis 3B, the results of Table 5 show that although connections with government officials are negatively correlated with the level of corporate donations, the coefficient is not significant. Hypothesis $3 \mathrm{~B}$ is reversed; however, this does not prove that there is no relationship between the two. Zhang, Marquis and Qiao [27] only considered the political connections of the CEO; their research identified a significant negative correlation between connections with government officials and corporate donation levels in private listed companies in China. The difference indicates that there may be a more complex relationship between connections with government officials and donation levels. This remains to be further studied. 
Table 5. Network effect on firm level.

\begin{tabular}{|c|c|c|c|c|c|}
\hline & (1) & (2) & (3) & (4) & (5) \\
\hline DEGREE & $\begin{array}{c}0.0193^{* * *} \\
(3.29)\end{array}$ & $\begin{array}{c}0.019^{* * *} \\
(3.20)\end{array}$ & $\begin{array}{l}0.019^{* * *} \\
(3.27)\end{array}$ & $\begin{array}{c}0.027^{* * * *} \\
(4.09)\end{array}$ & $\begin{array}{c}0.015^{* *} \\
(2.02)\end{array}$ \\
\hline FIRM_SIZE & $\begin{array}{l}1.241^{* * *} \\
(16.42)\end{array}$ & $\begin{array}{c}1.229 * * * \\
(16.29)\end{array}$ & $\begin{array}{l}1.248^{* * *} \\
(16.47)\end{array}$ & $\begin{array}{l}1.228^{* * *} \\
(16.27)\end{array}$ & $\begin{array}{c}1.248^{* * *} \\
(16.47)\end{array}$ \\
\hline SLACK_CASH & $\begin{array}{c}2.984^{* * *} \\
(3.64)\end{array}$ & $\begin{array}{c}2.919^{* * *} \\
(3.57)\end{array}$ & $\begin{array}{c}2.985^{* * *} \\
(3.64)\end{array}$ & $\begin{array}{c}2.942^{* * *} \\
(3.61)\end{array}$ & $\begin{array}{c}2.979 * * * \\
(3.63)\end{array}$ \\
\hline ADVE_INTE & $\begin{array}{c}0.166^{* * * *} \\
(5.12)\end{array}$ & $\begin{array}{c}0.162^{* * *} \\
(5.01)\end{array}$ & $\begin{array}{c}0.166^{* * *} \\
(5.12)\end{array}$ & $\begin{array}{c}0.163^{* * *} \\
(5.06)\end{array}$ & $\begin{array}{c}0.165^{* * *} \\
(5.11)\end{array}$ \\
\hline AGE_IPO & $\begin{array}{c}-0.063^{* * * *} \\
(-4.58)\end{array}$ & $\begin{array}{c}-0.060^{* * *} \\
(-4.31)\end{array}$ & $\begin{array}{c}-0.063^{* * * *} \\
(-4.53)\end{array}$ & $\begin{array}{c}-0.059^{* * *} \\
(-4.28)\end{array}$ & $\begin{array}{c}-0.062^{* * *} \\
(-4.53)\end{array}$ \\
\hline FIRM_PERF & $\begin{array}{c}5.020 * * * \\
(3.41)\end{array}$ & $\begin{array}{c}4.94^{* * *} \\
(3.38)\end{array}$ & $\begin{array}{c}5.000 * * * \\
(3.40)\end{array}$ & $\begin{array}{c}4.973^{* * *} \\
(3.41)\end{array}$ & $\begin{array}{c}4.988^{* * *} \\
(3.38)\end{array}$ \\
\hline NO_EXCE & $\begin{array}{c}-7.66 \times 10^{-6 * *} \\
(-2.01)\end{array}$ & $\begin{array}{c}-8.06 \times 10^{-6 * *} \\
(-2.12)\end{array}$ & $\begin{array}{c}-7.30 \times 10^{-6 *} \\
(-1.92)\end{array}$ & $\begin{array}{c}-8.15 \times 10^{-6 * *} \\
(-2.11)\end{array}$ & $\begin{array}{c}-7.28 \times 10^{-6 *} \\
(-1.92)\end{array}$ \\
\hline DUALITY & $\begin{array}{l}0.174 \\
(0.89)\end{array}$ & $\begin{array}{l}0.178 \\
(0.91)\end{array}$ & $\begin{array}{l}0.175 \\
(0.90)\end{array}$ & $\begin{array}{l}0.181 \\
(0.93)\end{array}$ & $\begin{array}{l}0.174 \\
(0.93)\end{array}$ \\
\hline LEVERAGE & $\begin{array}{c}0.113^{* * * *} \\
(4.17)\end{array}$ & $\begin{array}{c}0.112 * * * \\
(4.20)\end{array}$ & $\begin{array}{c}0.115^{* * *} \\
(4.20)\end{array}$ & $\begin{array}{c}0.112^{* * *} \\
(4.21)\end{array}$ & $\begin{array}{c}0.115^{* * *} \\
(4.20)\end{array}$ \\
\hline WOMEN & $\begin{array}{l}2.26^{* * *} \\
(3.08)\end{array}$ & $\begin{array}{c}2.212^{* * *} \\
(3.01)\end{array}$ & $\begin{array}{c}2.230 * * * \\
(3.03)\end{array}$ & $\begin{array}{c}2.188^{* * *} \\
(2.98)\end{array}$ & $\begin{array}{c}2.236^{* * *} \\
(3.04)\end{array}$ \\
\hline REPRESENT_PC & & $\begin{array}{c}6.573^{* * *} \\
(3.48)\end{array}$ & & $\begin{array}{c}5.708^{* * *} \\
(3.04)\end{array}$ & \\
\hline BUREAU_PC & & & $\begin{array}{l}-1.330 \\
(-1.06)\end{array}$ & & $\begin{array}{l}-1.234 \\
(-0.98)\end{array}$ \\
\hline $\begin{array}{c}\text { DEGREE } \\
* \text { * REPRESENT_PC }\end{array}$ & & & & $\begin{array}{c}-0.739^{* * *} \\
(-3.06)\end{array}$ & \\
\hline $\begin{array}{c}\text { DEGREE } \\
* \text { BUREAU PC }\end{array}$ & & & & & $\begin{array}{c}0.0760 \\
(0.79)\end{array}$ \\
\hline Industry fe & Yes & Yes & Yes & Yes & Yes \\
\hline Region fe & Yes & Yes & Yes & Yes & Yes \\
\hline Year fe & Yes & Yes & Yes & Yes & Yes \\
\hline R2-sq & 0.139 & 0.141 & 0.139 & 0.142 & 0.139 \\
\hline No. of obs & 6581 & 6581 & 6581 & 6581 & 6581 \\
\hline
\end{tabular}

The dependent variable is the companies' donation level. ${ }^{*}, * *$, and ${ }^{* * *}$ indicate significance at the 10,5 , and 1 percent levels, respectively. The OLS coefficients are reported, with the $t$-statistics in parentheses. Standard errors are corrected for by clustering the error term at the firm level. Constant is omitted.

\section{Discussion and Conclusions}

Hypothesis 1 in this paper argues that firm pairs with social connections are more similar in their donation level than those without social connections. Resume information was collected from the executives from listed firms in China to establish a matrix of connections between them and demonstrate that the linkages cause their donation behaviors to be more similar. The results from our analysis confirm this hypothesis. Since the Wenchuan earthquake in 2008, charitable donations have become a common method used by Chinese corporations to fulfill their social responsibilities. The level of corporate donations has been a significant concern among the public and stakeholders alike [56]. The externality of the donation decision-making in China deserves serious research. However, the related research mainly focuses on the plight of culture and system [36,57] and provides suggestions on countermeasures [58,59]. Thus, this paper further proves that donation decision-making is affected by social networks, making policy-making externalities seem sensible.

Moreover, Hypothesis 2 argues that there is a positive relationship between social network centrality and the corporate donation level. This hypothesis is confirmed as well. Previous research has concluded that the individual pursuit of prestige and status in society can encourage executives to make decisions in accordance with group ethics. Under these circumstances, executives will try to match the expectations of the network members to their own behavior $[17,25]$. Based on this, we also tested the relationship between corporate donations and the social network centrality, and proved that the higher the level of social network centrality, the higher the social status, and the higher the level of donation. This finding is in line with another study that examined the impact of director 
influences on political party donation activity from a network perspective [17]. Similar to our research, the researchers suggested a positive influence of managers' and directors' social network centrality on the corporate political donations in their corporations.

Next, Hypotheses $3 \mathrm{~A}$ and $3 \mathrm{~B}$ state that the relationships between social network centrality and donation level will be affected by political connections. In other words, we want to examine the impact of the combination of social networks and political networks on corporate donations. The related issues have not been discussed in previous literature. However, previous studies have shown that the government can shape corporate philanthropy through political connections $[15,60]$. All corporations need to adopt appropriate political strategies to cope with the external environment, and political connections are one of the most important representatives. Our findings partially confirm this hypothesis: we have only found a significant relationship between the NPC/CPPCC member connections and the effect of social network centrality. Therefore, the effects of connections with government officials still require further research.

\subsection{Theoretical and Practical Implications}

Our study contributes to the literature associated with corporate donation, social networks, and political connections in several ways. To start, we examine the diffusion effect of corporate donations through a social network's perspective. That verifies some of the views on the externality of decision-making, which are widespread in society [26]. This paper notes that a firm's donation decisions may be affected by their peers through the social network, providing evidence that decision externalities could also play an important role in corporate donation behavior. The conclusions not only broaden the existing research on charitable donation motivation, but also provide significant references for the government and related institutions to utilize in the formulation of social responsibility management systems. Furthermore, our results complement studies that suggest that corporate executives actively commit to proper social responsibility to enhance their reputation [61]. Companies in the center of a network will receive more attention from their peers, and therefore, may choose to donate in the belief that philanthropy can improve the company's reputation and status within their network. In particular, we examine the impact of social networks under different political connections; which highlights the importance of the institutional context of CSR studies. The institutional context is especially important in transition countries (e.g., China), as social economic activities can be affected. This leads to the final point: as far as we know, research on the relationship between social networks and corporate donation policies based on the latest data from the Chinese market has not been performed to date. This study is the first attempt in this field; thus, we are able to contribute to theory development while introducing academic audiences to this increasingly relevant domain. We believe that researchers cannot ignore the importance of social and political network in influencing corporate contributions and other corporate public service activities. We can see that social networks, political connections, and donation-related issues are attracting more and more attention in other countries' markets $[26,57,62,63]$. Prior literature has focused on the sharing of information between firms' management [3], as well as the influence of network resources on people's behavior. Thus, we have reason to believe that our results are interesting enough to motivate further inquiry and research on these issues.

To the best of our knowledge, no prior study has explored the diffusion effect of social networks on corporate donations. Our research may alert firm executives to the significant effect of social networks on donation behavior. In general, executives should realize that different firms may be in different network positions to take advantage of social networks. Such awareness may help to explain the unknown motivation factors of CSR. Then, as both political and corporate networks have significant roles in promoting donations, the government and related agencies should pay attention to the coordination and promotion of political and network conditions while deploying charitable activities. According to the empirical analysis conducted for this article, for the companies with the NPC/CPPCC connections, the government should pay attention to reducing the mutual influence 
between the social relations and the NPC/CPPCC connections in the process of promoting a company's philanthropy. In addition, highly interactive platforms for charity should be regarded as a current focus. According to our results, if the government can set up a more convenient donation strategy and a more transparent financial plan for corporations, the spread of philanthropy may be expanded. Social philanthropy would then experience a positive change, and corporations' influence would be maximized.

\subsection{Limitations and Future Research}

This study has several limitations. First, we have only explored one dimension of CSR: corporate donation amounts. We are not aware of whether or not a social network would have similar effects on other corporate socially responsible actions. Future studies could explore the effects of the network on other CSR activities.

Second, this study only confirms the impact of social networks on corporate donations. Nowadays, there are many studies on charitable motives. Although this provides a lot of reference for practice and theory in related fields, it also makes the knowledge framework too broad in scope. Future research can dig deeper into the association mechanisms between different motivations. Based on the certain accumulation of research, we can revise and perfect the existing theoretical model, establish new models that are integrated with other motivations, and promote the development of related research.

Finally, nowadays there is a growing interest in social relationships in academia $[3,64]$. This is because the relationship is a very important element in the governance of firms. With the rise of stakeholder management theory $[65,66]$, it is necessary for companies to use a variety of network relationships to obtain resources needed for development. Thus, the influence of social networks on charity is related to the interaction between enterprises and their stakeholders. Therefore, we account for a measure of the external interaction taking the degree of political connections. In this case, another question that should be raised is whether other variables affect the relationship between network centrality and donations.

Author Contributions: W.W. and S.-B.T. conceived and designed the experiments; K.Y. performed the experiments; W.W. and K.Y. analyzed the data; W.W. and S.-B.T. contributed reagents/materials/analysis tools; W.W. and K.Y. wrote the paper. W.W., C.-C.C., J.Z., H.X. revised the paper. All authors read and approved the manuscript.

Acknowledgments: This paper is supported by the National Social Science Foundation of China (Grant No. 17BGL025), National Natural Science Foundation of China (No. 71672089), Zhongshan City Science and Technology Bureau Project (No. 2017B1015), Shantou University Innovative and Strong School Project (No. 2015WQNCX031), National Natural Science Foundation of China (Grant No. 71602105), Natural Science Foundation of Guangdong Province of China (Grant No. 2016A030313073)and the Institute of Guangdong and Taiwan of Shantou University for their financial support.

Conflicts of Interest: The authors declare no conflict of interest.

\section{References}

1. Cohen, L.; Frazzini, A.; Malloy, C. The small world of investing: Board connections and mutual fund returns. J. Political Econ. 2008, 116, 951-979. [CrossRef]

2. Cai, Y.; Sevilir, M. Board connections and m\&a transactions. J. Financ. Econ. 2012, 103, 327-349. [CrossRef]

3. Cao, Y.; Dhaliwal, D.; Li, Z.Q.; Yang, Y.G. Are all independent directors equally informed? Evidence based on their trading returns and social networks. Manag. Sci. 2015, 61, 795-813. [CrossRef]

4. El-Khatib, R.; Fogel, K.; Jandik, T. Ceo network centrality and merger performance. J. Financ. Econ. 2015, 116, 349-382. [CrossRef]

5. Fracassi, C.; Tate, G. External networking and internal firm governance. J. Financ. 2012, 67, $153-194$. [CrossRef]

6. Wong, L.H.H.; Gygax, A.F.; Wang, P. Board interlocking network and the design of executive compensation packages. Soc. Netw. 2015, 41, 85-100. [CrossRef]

7. Shue, K. Executive networks and firm policies: Evidence from the random assignment of mba peers. Rev. Financ. Stud. 2013, 26, 1401-1442. [CrossRef] 
8. Butler, A.W.; Gurun, U.G. Educational networks, mutual fund voting patterns, and ceo compensation. Rev. Financ. Stud. 2012, 25, 2533-2562. [CrossRef]

9. Leonardi, P.M. Social media, knowledge sharing, and innovation: Toward a theory of communication visibility. Inf. Syst. Res. 2014, 25, 796-816. [CrossRef]

10. Tortoriello, M.; Reagans, R.; McEvily, B. Bridging the knowledge gap: The influence of strong ties, network cohesion, and network range on the transfer of knowledge between organizational units. Org. Sci. 2012, 23, 1024-1039. [CrossRef]

11. Rodan, S.; Galunic, C. More than network structure: How knowledge heterogeneity influences managerial performance and innovativeness. Strateg. Manag. J. 2004, 25, 541-562. [CrossRef]

12. Caskey, J.; Hughes, J.S.; Liu, J. Strategic informed trades, diversification, and expected returns. Acc. Rev. 2015, 90, 1811-1837. [CrossRef]

13. Hadani, M.; Coombes, S. Complementary relationships between corporate philanthropy and corporate political activity: An exploratory study of political marketplace contingencies. Bus. Soci. 2015, 54, 859-881. [CrossRef]

14. Brammer, S.; Millington, A. Does it pay to be different? An analysis of the relationship between corporate social and financial performance. Strateg. Manag. J. 2008, 29, 1325-1343. [CrossRef]

15. Wang, H.L.; Qian, C.L. Corporate philanthropy and corporate financial performance: The roles of stakeholder response and political access. Acad. Manag. J. 2011, 54, 1159-1181. [CrossRef]

16. Mellahi, K.; Frynas, J.G.; Sun, P.; Siegel, D.S. A review of the nonmarket strategy literature: Toward a multi-theoretical integration. J. Manag. 2016, 42, 143-173. [CrossRef]

17. Lu, Y.; Shailer, G.; Wilson, M. Corporate political donations: Influences from directors' networks. J. Bus. Ethics 2016, 135, 461-481. [CrossRef]

18. Yoon, Y.; Gurhan Canli, Z.; Schwarz, N. The effect of corporate social responsibility (csr) activities on companies with bad reputations. J. Consum. Psychol. 2006, 16, 377-390. [CrossRef]

19. Grau, S.L.; Folse, J.A.G. Cause-related marketing ( $\mathrm{crm})$ - The influence of donation proximity and message-framing cues on the less-involved consumer. J. Advert. 2007, 36, 19-33. [CrossRef]

20. Lin, N. Social Resources and Instrumental Action, 1st ed.; Sage Publications: Los Angeles, CA, USA, 1981.

21. Nielsen, A.E.; Thomsen, C. Sustainable development: The role of network communication. Corp. Soc. Resp. Environ. Manag. 2011, 18, 1-10. [CrossRef]

22. Guimaraes-Costa, N.; Cunha, M.P.E. The atrium effect of website openness on the communication of corporate social responsibility. Corp. Soc. Resp. Environ. Manag. 2008, 15, 43-51. [CrossRef]

23. Apinunmahakul, A.; Devlin, R.A. Social networks and private philanthropy. J. Public Econ. 2008, 92, 309-328. [CrossRef]

24. Martin, R.; Randal, J. How is donation behaviour affected by the donations of others? J. Econ. Behav. Org. 2008, 67, 228-238. [CrossRef]

25. Saxton, G.D.; Wang, L.L. The social network effect: The determinants of giving through social media. Nonprof. Volunt. Sec. Q. 2014, 43, 850-868. [CrossRef]

26. Fracassi, C. Corporate finance policies and social networks. Manag. Sci. 2016, 63, 2420-2438. [CrossRef]

27. Zhang, J.J.; Marquis, C.; Qiao, K.Y. Do political connections buffer firms from or bind firms to the government? A study of corporate charitable donations of chinese firms. Org. Sci. 2016, 27, 1307-1324. [CrossRef]

28. Francis, B.B.; Hasan, I.; Sun, X. Political connections and the process of going public: Evidence from china. J. Int. Money Financ. 2009, 28, 696-719. [CrossRef]

29. Scott, J. Social Network Analysis: A Handbook, 2nd ed.; Sage Publications: Newbury, Park, CA, USA, 1991.

30. Konrad, A.M.; Radcliffe, V.; Shin, D. Participation in helping networks as social capital mobilization: Impact on influence for domestic men, domestic women, and international mba students. Acad. Manag. Learn. Educ. 2016, 15, 60-78. [CrossRef]

31. Chen, W.J.; Kamal, F. The impact of information and communication technology adoption on multinational firm boundary decisions. J. Int. Bus. Stud. 2016, 47, 563-576. [CrossRef]

32. Lin, Y.N.; Wu, L.Y. Exploring the role of dynamic capabilities in firm performance under the resource-based view framework. J. Bus. Res. 2014, 67, 407-413. [CrossRef]

33. Haunschild, P.R. Interorganizational imitation: The impact of interlocks on corporate acquisition activity. Admin. Sci. Q. 1993, 38, 564-592. [CrossRef] 
34. Westphal, J.D. Collaboration in the boardroom: Behavioral and performance consequences of ceo-board social ties. Acad. Manag. J. 1999, 42, 7-24. [CrossRef]

35. Carroll, A.B.; Shabana, K.M. The business case for corporate social responsibility: A review of concepts, research and practice. Int. J. Manag. Rev. 2010, 12, 85-105. [CrossRef]

36. Miras-Rodriguez, M.D.; Carrasco-Gallego, A.; Escobar-Perez, B. Are socially responsible behaviors paid off equally? A cross-cultural analysis. Corp. Soc. Resp. Environ. Manag. 2015, 22, 237-256. [CrossRef]

37. Godfrey, P.C.; Merrill, C.B.; Hansen, J.M. The relationship between corporate social responsibility and shareholder value: An empirical test of the risk management hypothesis. Strateg. Manag. J. 2009, 30, 425-445. [CrossRef]

38. Reynolds, S.J.; Ceranic, T.L. The effects of moral judgment and moral identity on moral behavior: An empirical examination of the moral individual. J. Appl. Psychol. 2007, 92, 1610-1624. [CrossRef] [PubMed]

39. Richman, S.B.; DeWall, C.N.; Wolff, M.N. Avoiding affection, avoiding altruism: Why is avoidant attachment related to less helping? Pers. Indiv. Differ. 2015, 76, 193-197. [CrossRef]

40. Gautier, A.; Pache, A.C. Research on corporate philanthropy: A review and assessment. J. Bus. Ethics 2015, 126, 343-369. [CrossRef]

41. Atkinson, L.; Galaskiewicz, J. Stock ownership and company contributions to charity. Admin. Sci. Q. 1988, 33, 82-100. [CrossRef]

42. Hampton, K.N.; Lee, C.J.; Her, E.J. How new media affords network diversity: Direct and mediated access to social capital through participation in local social settings. New Media Soc. 2011, 13, 1031-1049. [CrossRef]

43. Hochberg, Y.V.; Ljungqvist, A.; Yang, L.U. Whom you know matters: Venture capital networks and investment performance. J. Financ. 2007, 62, 251-301. [CrossRef]

44. Brass, D. Connecting to brokers: Strategies for acquiring social capital. In Social Capital: Reaching out, Reaching in, 1st ed.; Bartkus, V., Davis, J., Eds.; Edward Elgar Press: Cheltenham, UK, 2009; pp. 260-274.

45. Oto-Peralias, D.; Romero-Avila, D. The consequences of persistent inequality on social capital: A municipal-level analysis of blood donation data. Econ. Lett. 2017, 151, 53-57. [CrossRef]

46. Witt, P. Entrepreneurs' networks and the success of start-ups. Entrep. Reg. Dev. 2004, 16, 391-412. [CrossRef]

47. Huggins, R. Forms of network resource: Knowledge access and the role of inter-firm networks. Int. J. Manag. Rev. 2010, 12, 335-352. [CrossRef]

48. Lin, C.P.; Hung, W.T.; Chiu, C.K. Being good citizens: Understanding a mediating mechanism of organizational commitment and social network ties in ocbs. J. Bus. Ethics 2008, 81, 561-578. [CrossRef]

49. Costenbader, E.; Valente, T.W. The stability of centrality measures when networks are sampled (vol 25, pg 283, 2003). Soc. Netw. 2004, 26, 351. [CrossRef]

50. Faccio, M. Politically connected firms. Am. Econ. Rev. 2006, 96, 369-386. [CrossRef]

51. Gao, Y. Philanthropic disaster relief giving as a response to institutional pressure: Evidence from china. J. Bus. Res. 2011, 64, 1377-1382. [CrossRef]

52. Lester, R.H.; Hillman, A.; Zardkoohi, A.; Cannella, A.A. Former government officials as outside directors: The role of human and social capital. Acad. Manag. J. 2008, 51, 999-1013. [CrossRef]

53. Marquis, C.; Qian, C.L. Corporate social responsibility reporting in china: Symbol or substance? Org. Sci. 2014, 25, 127-148. [CrossRef]

54. Hillman, A.J. Politicians on the board of directors: Do connections affect the bottom line? J. Manag. 2005, 31, 464-481. [CrossRef]

55. Sauerwald, S.; Lin, Z.; Peng, M.W. Board social capital and excess ceo returns. Strateg. Manag. J. 2016, 37, 498-520. [CrossRef]

56. Jia, M.; Zhang, Z. Managerial ownership and corporate social performance: Evidence from privately owned chinese firms' response to the sichuan earthquake. Corp. Soc. Responsib. Environ. Manag. 2013, 20, 257-274. [CrossRef]

57. Jamali, D.; Neville, B. Convergence versus divergence of csr in developing countries: An embedded multi-layered institutional lens. J. Bus. Ethics 2011, 102, 599-621. [CrossRef]

58. Xu, S.K.; Yang, R.D. Indigenous characteristics of chinese corporate social responsibility conceptual paradigm. J. Bus. Ethics 2010, 93, 321-333. [CrossRef] 
59. Kao, T.Y.; Chen, J.C.H.; Ben Wu, J.T.; Yang, M.H. Poverty reduction through empowerment for sustainable development: A proactive strategy of corporate social responsibility. Corp. Soc. Resp. Environ. Manag. 2016, 23, 140-149. [CrossRef]

60. Ma, D.L.; Parish, W.L. Tocquevillian moments: Charitable contributions by chinese private entrepreneurs. Soc. Forces 2006, 85, 943-964. [CrossRef]

61. Dean, D.H. Consumer perception of corporate donations-Effects of company reputation for social responsibility and type of donation. J. Advert. 2003, 32, 91-102. [CrossRef]

62. Collins, C.J.; Clark, K.D. Strategic human resource practices, top management team social networks, and firm performance: The role of human resource practices in creating organizational competitive advantage. Acad. Manag. J. 2003, 46, 740-751.

63. Kostovetsky, L. Political capital and moral hazard. J. Financ. Econ. 2015, 116, 144-159. [CrossRef]

64. Webb, D.A.; Sweeney, J.C. How functional, psychological, and social relationship benefits influence individual and firm commitment to the relationship. J. Bus. Ind. Mark. 2007, 22, 474-488. [CrossRef]

65. Hörisch, J.; Freeman, E.; Schaltegger, S. Applying stakeholder theory in sustainability management. Links, similarities, dissimilarities, and conceptual framework. Org. Environ. 2014, 27, 328-346. [CrossRef]

66. Mok, K.Y.; Shen, G.Q.; Yang, J. Stakeholder management studies in mega construction projects: A review and future directions. Int. J. Proj. Manag. 2015, 33, 446-457. [CrossRef]

(C) 2018 by the authors. Licensee MDPI, Basel, Switzerland. This article is an open access article distributed under the terms and conditions of the Creative Commons Attribution (CC BY) license (http:// creativecommons.org/licenses/by/4.0/). 